Archives of Agriculture and Environmental Science

\title{
Drudgery reduction for women in agriculture sector in Nepal: An analytical study
}

\author{
Urmila Aryal ${ }^{1}$ (D) and Rishi Ram Kattel ${ }^{2^{*}}$ \\ ${ }^{1}$ Former Minister, Ministry of Local Development, and Ministry of Women, Children and Social Welfare, Suryabinayak Municipality, \\ Bhaktapur, Kathmandu, NEPAL \\ ${ }^{2}$ Department of Agricultural Economics and Agribusiness Management, Agriculture and Forestry University, Rampur, Chitwan, \\ NEPAL \\ *Corresponding author's E-mail: rrkattel@afu.edu.np
}

\section{ARTICLE HISTORY}

Received: 15 October 2019

Revised received: 03 December 2019

Accepted: 04 December 2019

\section{Keywords}

Agriculture sector

Drudgery

Feminization

Nepal

Women

\section{ABSTRACT}

Analysis of rural womens' livelihood identifies a 'triple burden' of work to in the productive, reproductive and social spheres. Feminization is the common phenomenon in Nepal where the roles of men and women are unbalanced at household and community level. Due to the migration of economically active men to other countries and urban area for better jobs, the agricultural labor is being increasingly feminized. This paper assesses factors influencing the women drudgery in agriculture sector, possible interventions and recommendation for reducing such drudgery. It consisted desk review, key informant interview and stakeholders' consortium meetings to collect information, and triangulation of findings during 2017-2019 at regional and national levels. The study suggests that the workload of women (e.g., time and energy) in the farming activities can be reduced in two ways: (1) making existing tasks easier or increasing the productivity of existing labor, or (2) changing farm practices with new technology. Changes in the existing practice or introduction of new technology often reduces the workload of women in terms of both time and energy, but it requires external inputs and extra knowledge and coaching. Such interventions must consider the aspects of wider acceptance, economic viability and environmental friendliness. Further, the mechanization of agricultural tools and technology have alleviated the burden of tasks traditionally handled by both men and women in the sector. This paper recommends major tools, techniques and skills for women drudgery reduction in agriculture sector in Nepal that will be equally applicable in Asian region.

(C)2019 Agriculture and Environmental Science Academy

Citation of this article: Aryal, U. and Kattel, R.R. (2019). Drudgery reduction for women in agriculture sector in Nepal: An analytical study. Archives of Agriculture and Environmental Science, 4(4): 449-463, https://dx.doi.org/10.26832/24566632.2019.0404012

\section{INTRODUCTION}

Nepal's Gender Inequality Index rating was 0.56 (113 out of 146 countries) in 2011 but it improved to 0.480 (149 out of 189 countries) in 2018 (UNDP, 2018). The country was in the $126^{\text {th }}$ place in the Global Gender Gap Index for 2011, with a score of 0.59. By 2017, the Gender Development Index reached to 0.920 (149 out of 189 countries). This is a case of medium human development (UNDP, 2018). Women perform triple roles, i.e. productive, reproductive and community (World Economic Forum, 2017). A substantial proportion (40 percent) of the Nepalese women employed in agriculture as economically active work force. They work primarily as family unpaid workers in subsistence agriculture with low technology and primitive farming practices. They have to work long hours because they carry double burden of work in the family and farm. With the increasing outmigration and engagement on other non-farming sectors of male members, agriculture is becoming increasingly feminized. round 83 percent of the people lived in the rural area. Agriculture forms the foundation of the economy, accounting for around a third of GDP and providing an income for three quarters of the population. Women supply around 65 percent of labor in agricultural activities (FAO, 2010).

The share of agriculture in the gross domestic production (GDP) 
declined to 26.5 percent by 2018/19 (MoF, 2019). The share of agriculture in the employment is also declining. Nepal conducted the Nepal Labor Force Survey (NLFS) (CBS, 1998; CBS, 2008; CBS, 2019). Form these surveys, the employment by industry shows that the share of agriculture in the employment has drastically declined to 21.5 percent as shown in Figure 1 below. It is noteworthy that the share of agriculture in total employment declined from 76 percent in 1997-98 to 74 percent by 2007-08, and further to 21.5 percent by $2017-18$ (CBS, 1998; CBS, 2008; CBS, 2019). Part of this decline is due to the definition of the data because the NLFS $1997 / 98$ and 2007/08 took the age group of 10 years of age and above, but the 2017/18 took the age group of 15 years and above. The general trend is that the employment in agriculture has been declining very fast due to the drudgery of the work, out-migration, growth of service sector and other factors. This has adversely affected in the national food security, which is reflected in the rapid increases in the agricultural balance of payments in the international trade. Further among the work force employed in agriculture, majority of them have always been women. This underlines the need to improve the innovations in agriculture such that it is more productive, labor saving and women- friendly.

Women are the most important actors in enhancing the agricultural and rural development in Nepal. However, they are facing greater constraints than their male counterparts in gaining access to public service, control over resource, social protection, employment opportunity, information, innovation and market and institution. A large number of women They are confined in unpaid care-work, and they encounter more difficulties in taking up leadership positions. A number of studies have reported that there is need to conduct gender research and analysis in a wide range of policy areas to support in the gender responsive policy formulation, implementation and social change in the country
(World Bank, 2009). In order to rectify these challenges as well as uphold the Government's political commitment to prioritize the Gender Equality and Social Inclusion (GESI) across sectors, the Ministry of Agriculture and Livestock Development (MoALD) has emphasized GESI integration in the Agriculture Development Strategy (GoN/ADS, 2014). The importance of production of evidence-based/ knowledge products for GESI responsive policy and program in the agriculture sector as stated in the output 1.5 of ADS underlines the scope of this research. Therefore, this study carries out a desk review of existing researches conducted by the government, public and private academic/ research institutions in the agriculture sector for last 10 years (2005-2016) on drudgery reduction for women in the agriculture sector in order to: (1) stock take/ summarize the existing information on relevant subjects, and (2) identify the gaps between available information and required information that would help the Government to make evidencebased policy and programs.

\section{MATERIALS AND METHODS}

The study is based on the desk review and few key informant interviews with the concerned stakeholders for qualitative information. The key informant interviews (KII) was applied to verify and/or supplement the secondary data and information with key government officials of line ministries, UN agencies and other donors and major stakeholders.

\section{Data collection methods}

The data collection methods mainly consisted of desk review of available documents, literature and findings from Nepal and other South Asia mainly India, Pakistan and Bangladesh from 2005 to 2019 and administration of the KII with the government GESI and ADS focal points, and the private sectors.
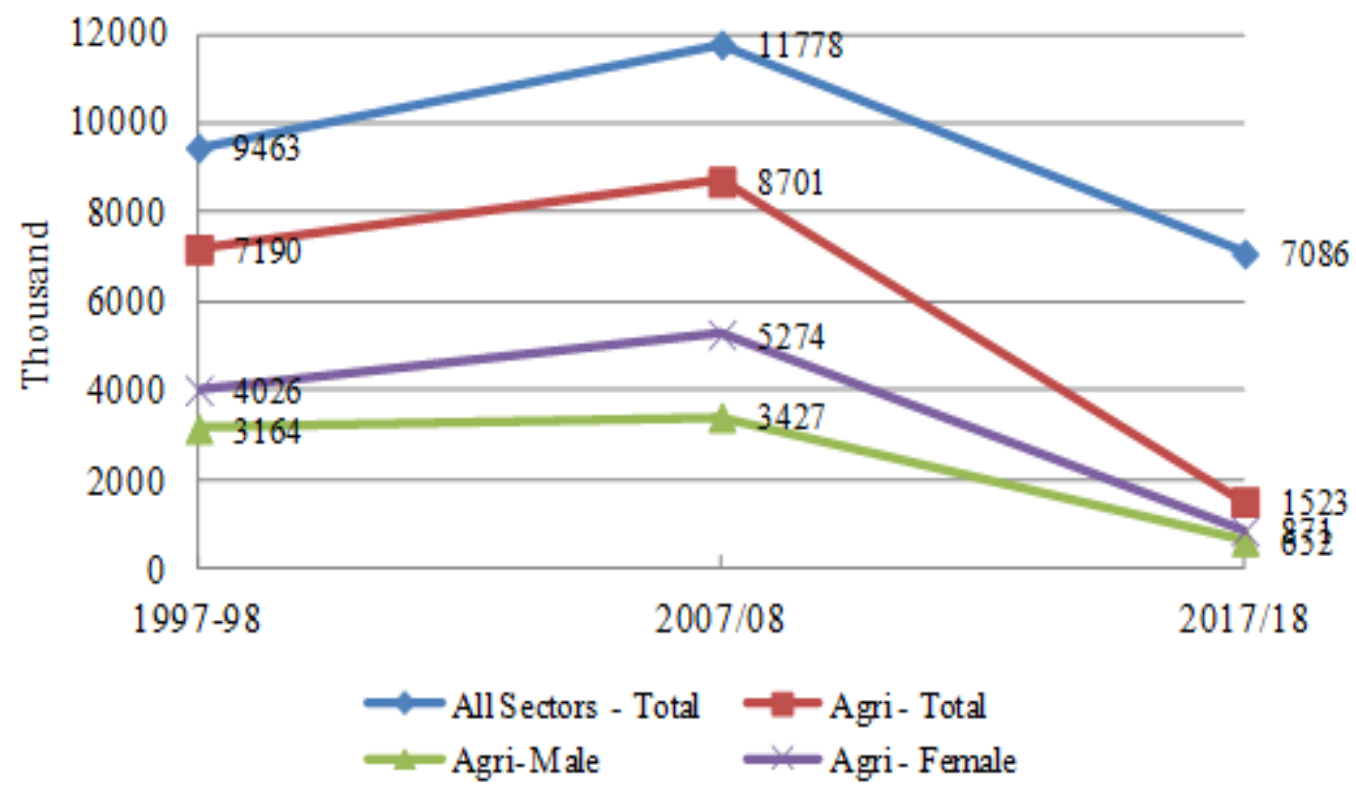

Figure 1. Employment in the economy, and the agriculture, forestry and fishery sector by male, female category 1998,2008 and 2017 (Sources: CBS, 1998, 2008 and 2019). 
Criteria for desk review

The following were the desk review criteria and questions to guide this research. The specific data of interest included:

- Contribution of women, and their age, education, years of experience, farm size, property rights, ethnicity, well-being, male-migration, marital status and workload sharing in agriculture and livestock management; these activities included procurement of farming inputs; harvesting, storage, marketing, saving, and technology adoption in farming systems.

- Gender involvement such as the socio-economic aspects in agriculture sector and workload sharing mechanism to reduce drudgery in the rural and urban areas.

- Gender roles and contribution in the farming systems and technology adoption.

- Women's role and contribution in the farmers, groups, cooperatives and other institution.

Key research questions for desk review of research to reduce drudgery for women in agriculture sector were: How to reduce drudgery of women in agriculture sector?, What factors and key variables influence in drudgery reduction for women?, What are the enabling and distracting variables for drudgery reduction of women?, What are the key technology and intervention needed to reduce drudgery of women in agriculture sectors?, Which policy and interventions influenced drudgery reduction for women?, What are the gaps and recommendations?

\section{Key informant interviews (KII)}

Face-to-face KII were conducted with project officials and key stakeholders at the national level with the representatives from Government and private sectors as follows:

\section{- GESI and ADS focal points at MoALD.}

- Nepal Agriculture Research Council (NARC)' GESI focal points.

- $\quad$ Focal persons of Agricultural Engineering Division (AED), NARC.

- Professors at Agriculture and Forestry University (AFU) and Institute of Agriculture and Animal Science (IAAS)/ Tribhuvan University.

- Swiss Agency for Development and Cooperation (SDC), Helvetas Nepal, ICIMOD key focal persons.

- $\quad$ Agriculture Food Security Project (AFSP)/FAO and OXFAM focal persons and discussed in related and relevant issues related to drudgery reduction for women.

\section{RESULTS AND DISCUSSION}

\section{Women in agriculture}

There is a vast difference between the male and female engagement rate in agriculture with about 51 percent and 74 percent, respectively (CBS/NPHC, 2011). Overall, literacy rates in- creased to 67 percent by 2011 from 54 percent in 2001. Female literacy has increased from 43 percent in 2001 to 58 percent in 2011, which places Nepal in fourth position among SAARC countries above Bhutan, Pakistan, Bangladesh, and Afghanistan. In Nepal, about 65 percent of the women contribute their time in agriculture sector whereas male's contribution is only 35 percent (FAO, 2011a). Data recorded in the successive census by CBS reflects that women's participation in agriculture labor force has increased from 36 percent in 1981 to 45 percent in 1991 to 48.1 percent in 2001 and further made a jump about 65 percent in 2011 (CBS, 2012; FAO, 2010). Women are the backbone of agricultural work force but their hard work remained mostly unpaid and not countable. Women do the most tedious and back breaking tasks in agriculture. Female-headed households have increased by 11 percent points from 14.8 percent in 2001 to 25.7 percent in 2011. Among the heads of agriculture holdings, 31.7 percent of males and 44.4 percent of females are still illiterate. Average land holding in Nepal is 0.68 ha, which is higher among the male farmers ( $0.7 \mathrm{ha}$ ) as compared to female farmers (0.4 ha). The land holding size is found higher in terai ( $0.75 \mathrm{ha}$ ) followed by mountain $(0.65 \mathrm{ha})$ and lower in hill region of Nepal (0.57 ha). Out of the total major farmers in Nepal, 8 percent were female in 2001 which was increased by 19 percent in 2011-12.

Government's agriculture policy and strategy has not touch much on women farmers. For example, in the Agriculture Perspective Plan (APP 1995-2015), policy failure is one of the reasons for the increasing trend of outmigration. Despite increasing rate of remittance to GDP (29.1 percent in 2014/15) (MoF, 2016), agriculture has been feminized increasing women's workload because the crops/ livestock management practices are traditional, with limited use of machines and tools, and poses serious health implication for women (LI-BIRD, 2015). Nevertheless, there are certain positive results on socioeconomic empowerment of women. The gender responsive budget has been increased from 11.09 percent to 22.27 percent in ten years from 2006 (MoF, 2016).

The gender responsive budget (GRB) in agriculture is oriented primarily towards the livelihood support such as food security, income generation and marketing in total (59 percent), which is followed by budget allocation for extension education (41 percent) during 2014-2018 (Figure 2). The budget allocation for agricultural technology innovation from the gender point of view is very less. The National Agricultural Research System (NARCS) does have a unit to examine the gender implications of the agricultural technology one the technology is generated, but there is no procedure to include the gender agenda in the design of research for technology (Figure 3).

Among the employed labor force, the distribution for economic and non-economic work shows gender gap in the national and the urban and rural sectors. At the national level, 21.3 percent female are engaged in non-economic work whereas only 5 percent male are engaged in such work. In economic work, 37.5 percent female and 44.9 percent male are engaged. This shows a high inclination to economic work by the male while for non- 


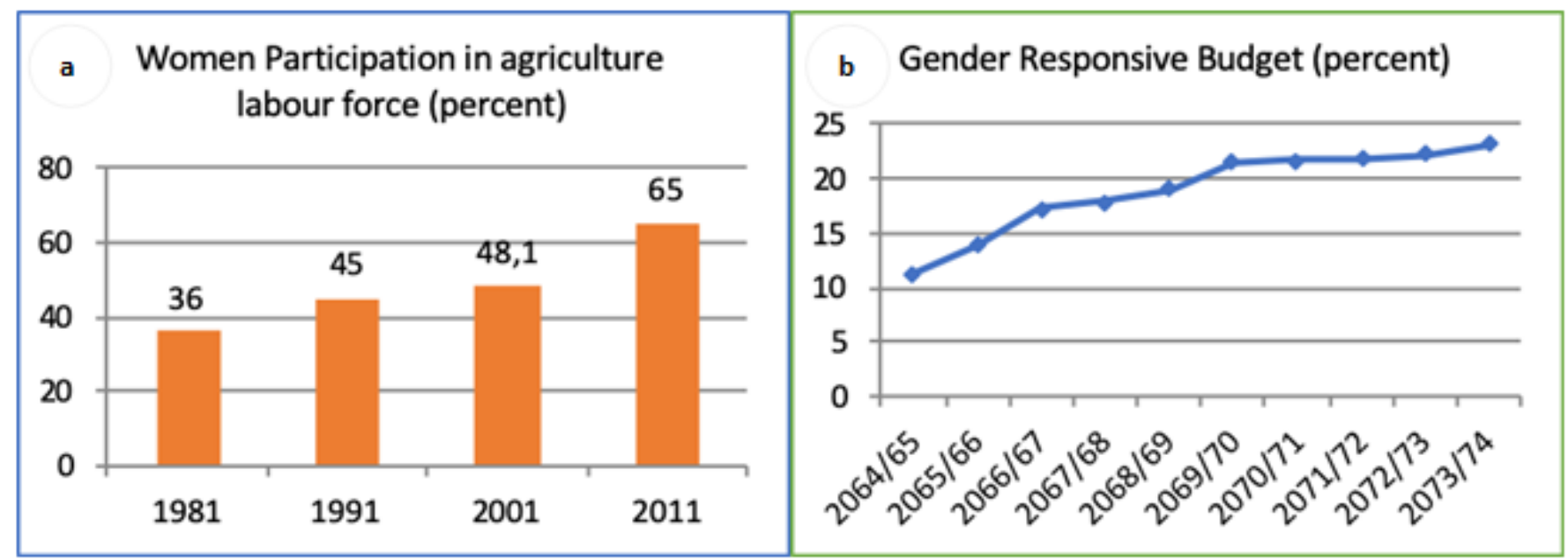

Figure 2. (a) Women participation in agriculture labor force, (b) Gender responsive budget in Nepal.

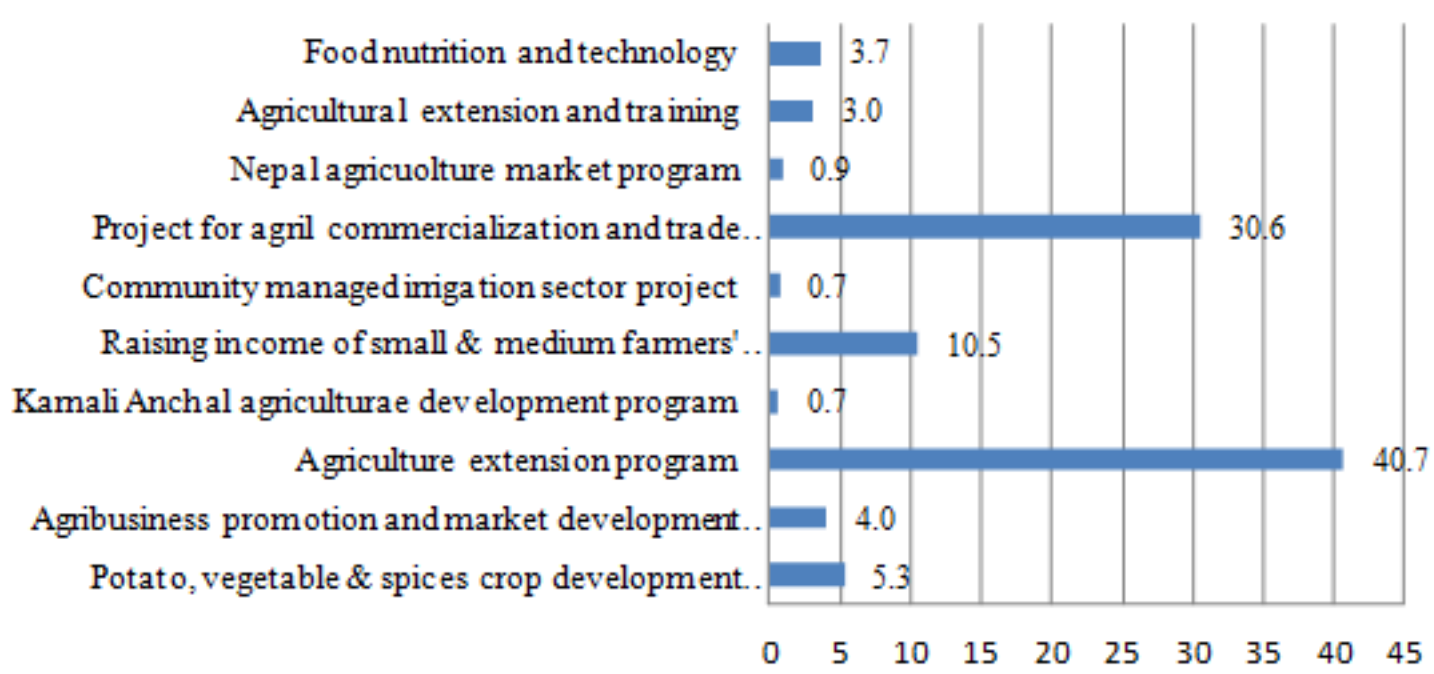

Figure 3. Scenario of P1 program budget allocation with GRB code 1 in agriculture sector (percent share, 2014-2018) (Source: MoAD, 2018).

economic work, more females are involved. Such gender gap is more prominently seen in urban area where 21.8 percent female and 5.2 percent male are engaged in non-economic work. In all work, female are found working on weekly average for 58.8 hours, whereas male work for 49.9 hours that shows female work on average 8.9 more hours weekly than male. However, female are highly engaged in non-economical or unpaid types that include household chores, self-agriculture work and so on. On average, female work 16.3 hours more in non-economic works than male whereas male labor is engaged in economic or paid works for 7.4 hours more than female (CBS, 2016).

In agriculture sector, 33 percent male received high wage rate whereas 4.1 percent female received that much among all the participants in rural wage employment (FAO, 2011a). The majority of Nepali women received low wage (61.4 percent) rate in agriculture employment, which is similar to global average (62 percent). However, very few and negligible Nepali women have received higher wage (1 percent) that is very low as compared to global average (19.8 percent). Figure 2 shows the employment in agriculture and percentage of female employment in the world, South Asia and Nepal.
Drudgery for women in agriculture sector

Feminization of agriculture is evident in the outmigration of male from rural areas. Women actively make management decisions on inputs supply, planting, weeding, post-harvest operations and marketing of the produce. The crop management practices they follow are traditional, with limited the uses of machines and tools, causing backache and whole-body pain. FAO (2005) reported that the majority of household labor and their livelihood activities are characterized by mounting drudgery-collecting water and firewood from far distance, and laborintensive agricultural tasks. This work 'overload' is mostly unpaid and unrecognized. And restricts women's well-being and their engagement in activities of value, including remunerative activities.

In the Feminization, the roles of men and women are unbalanced at household or community level. This is happening due to globalization and advances in transportation and communication because it led the young people to migrate outside of their home country in search of a better life and job. Due to economic active male family member migration for better job opportunity to abroad, the agricultural labor is being increasingly feminized 
(Kollmair and Hoermann, 2011; Gartaula et al., 2010; Kelker, 2009). Women face a distinct disadvantage since they are the ones who sacrifice education and skill development opportunities to manage land and agriculture. With massive male migration, women have broadened and deepened their involvement in agricultural work. So they are increasingly shouldering the responsibilities for household survival, productive, reproductive and responsibilities work in the household and community (Kelker, 2009). The feminization of agriculture has a deep and wide-ranging impact of agriculture productivity. Numerous studies have shown that with the feminization of agriculture is already happening, its causes and consequences on drudgery for women has been increased due to burden in agriculture work, household other work and off-farm activities simultaneously (Tamang et al., 2014; Poudel et al., 2012; Amatya Shrestha et al., 2010; Gartaula et al., 2010; Maharjan, 2010; Kelker, 2009). Out-migration has some positive benefits in the form of skill enhancement of migrants, remittance to the families back home, capital formation (asset creation) and their livelihood diversification. Albeit, there are many negative social impacts from men out-migration to abroad such as family stress, increased drudgery for women in agriculture, family breakdown, children growing up without their father among others (Kattel and Uphadhyay, 2018). Tamang et al. (2014) field study suggested that the less labor-intensive agro-forestry approach is a found to be vital for addressing the agriculture productivity issues and increase local food production for food security of the poor and marginalized, restoring abandoned agricultural land in full production cycle. Amatya Shrestha et al. (2012) reported that women involvement in agricultural activities was 16 percent higher than that of men in Mangaltar VDC of Kavre district. In the irrigated area, women involved more than 11 hours a day whereas men contributed only 7 hours in agricultural activities. In the rainfed area, women devoted more than 12 hours a day, whereas men contributed only 9 hours. Majority of activities of male farmers were ploughing and levelling the land during land preparation, and hard works like carrying out product loads after the harvesting. The authors argue that as female farmers are more engaged in farming activities than male farmers and sources of drudgery for rural women. Based on the field experience they concluded that technology interventions in agricultural sector in Nepal have hardly addressed the issues and concerns on gender. In this changing context, there is a need to identify an effective and gender balanced technology in the different agro-ecological zones of Nepal. The agricultural technology should be women-friendly to reduce the drudgery of female farmers.

Women continue to have extensive workloads with major responsibilities for agriculture production/marketing, animal husbandry and household chores (Leduc, 2011). Gender stereotypes and outmigration of men to urban areas and foreign countries for employment have increased the responsibilities of women in relation to agriculture production and natural resource management, intensifying their workload (Khadka, 2012). Outmigration is both an enormous challenge for women as well as an opportunity when we consider the empowerment of women and livelihood strategy. However, most of the existing agricultural technologies are not women friendly because the technology are focused on external resources, but not on the intensive workloads and, when appropriate technology are available, they are often expensive and subject limited ownership of the women. In addition to these, several institutional, financial and human resource factors limit agriculture service delivery to farmers in Nepal, especially to rural women in more remote areas. Moreover, access to extension services and skills by women is very limited because of the lack of a gender sensitive extension system (Ghale, 2008); as a result, gender-friendly programs and activities at the beneficiary level are very limited.

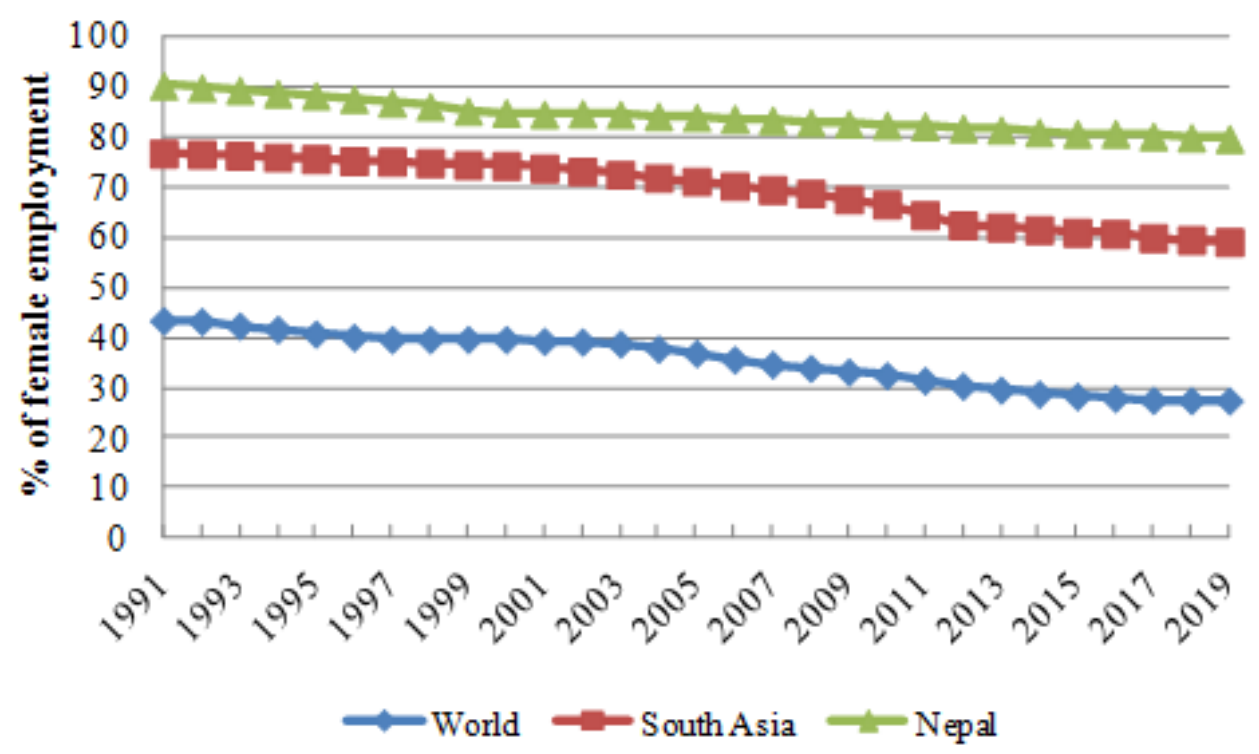

Figure 4. Employment in agriculture, female (percent of female employment) (modeled ILO estimate) (Source: World Bank Group, 2019). 
Women's drudgery reducing approaches, innovations and technologies

Various research and project assessment studies in Nepal showed that access to road and transportation, sustainable energy, infrastructure facilities, mechanization in agriculture with gender-friendly technology, access to credit, services, water and women's ownership right can reduce drudgery in agriculture sector (Ragasa et al., 2014; Tamang et al., 2014; Ghebremichael, 2013; UNIDO/UN Women, 2013; Joshi et al., 2012; Leduc, 2011; Gurung et al., 2011; FAO, 2010; Sharma, 2010; Kelker, 2009; Manandhar et al., 2009; Ghimire, 2008; FAO, 2005). Mechanization of agricultural tools and technology alleviated the burden of tasks that are traditionally handled by men, leaving women's burden unrelieved (Shiva, 1991 as cited in Tamang et al., 2014). Ragasa et al. (2014) analyzed the access to and adoption of technologies that reduced drudgery for women in agriculture sector by looking at both the supply and demand sides of technology and related services (Figure 4). The demand side relates to users of services and technology, while supply side concerns to the developers of input suppliers, technology and service providers. The former includes different types of farmers and other supply chain actors who are the anticipated users of technology and services. The latter includes the (i) research system that provide scientific and technical expertise and indigenous knowledge; and (ii) education and extension systems (trainers, subject matter specialists, front-line field workers either from public sector, private sector, nongovernment organizations, or other civil society organizations) that provide training, education and advisory services on technology, management practices and livelihood strategies. On the types of technology, improved practices and innovations particularly focus on agriculture/value chain where women are more involved and helped their drudgery reduction, it examines are as follows (Ragasa et al., 2014).

- Agriculture production technologies (e.g., improved varieties and seeds, improved production or natural resource management practices, fertilizer, pesticides, knapsack sprayers, plows, irrigation, and other farm power);

- Harvesting technologies (e.g., hand tools, reapers);

- Postharvest operations and processing technologies (e.g., solar drying equipment, threshers, improved marketing or processing practices);

- Labor, time and energy-saving technologies for household tasks (e.g., fuel-efficient stoves, home gardens, technological and institutional innovations for greater access to water and energy);

- Rural transport (e.g., hand carts, bicycles, motorized transport and other means of transport);

- Information and communication technology (ICT) such as mobile phones, rural radio, internet, television, print media.

\section{Access to road and transportation facilities}

Many research findings in Nepal show that rural road and means of transportation can reduce drudgery for rural women through market linkage of products, inputs and services and income generation opportunities to the women. For example, women in Kaule village of Chitwan (hilly area) carried load about 30-50 kilogram of rainy and winter season vegetables and walked from Hatibang to Fishling had taken about 4-6 hours a day before rural road connection. Now, their workload to market supply of vegetable has been reduced by $80-90$ percent due to rural road connectivity and transport facility in this area. Leduc (2011) reported that construction of road and footpaths under North Eastern Region Community Resource Management Project for Upland Area (NERCORMP), India, reduce women's drudgery, and increases the market linkages for products. Similarly, World Bank, FAO and IFAD (2008) suggest that rural roads increase the productivity and income for men and women farmers by reducing drudgery, time and opportunity cost to marketing and inputs. Gravity ropeway technology was transferred from Northern India to Nepal in collaboration with ICIMOD and private manufacturers/suppliers. An initial study showed that the gravity ropeway system reduced transportation cost of agro products by at least half. It gave villagers and women confidence to supply vegetables, milk and other perishable agricultural and forest products in larger amounts, and to enter the competitive market in cities. It reduced drudgery for load carrying by women, and improved their socio-economic conditions (health, education, and convenience), created employment opportunities and supported the business of local manufacturers and service providers (Biggs and Justice, 2011; Manandhar et al., 2009).

\section{Sustainable energy}

Among the several renewable resources, the biogas, microhydropower, improved cooking stove (ICS), rice husk stoves for cooking reduce the drudgery for women by increasing access to modern agro-processing mill, time saving for cooking and other household chores. Several studies in Nepal reported that renewable and sustainable energy promotion help reducing women's drudgery in agriculture sector. For example, a study conducted by Gurung et al. (2011) in Parche VDC, Kaski district revealed that access to electricity reduces drudgery for women in rural areas allowing them to have enough time to be involved in other household related activities including the income generation, social and community development and self-employment activities. Similarly, biogas reduces drudgery and save work time, and rice husk stoves for cooking reduce women drudgery for fuelwood collection (Manandhar et al., 2009). The ICIMOD project findings showed that improved cooking stove in Nepal and solar dryer in Bhutan helped drudgery reduction for women through production, marketing and utilization of these technologies using productive and strategic gender participation approach. This brought gradual change in the traditionally defined gender roles with women taking up so-called 'male responsibilities', and men showing increased involvement in household chores previously considered as 'women responsibilities' (Sharma, 2010). 


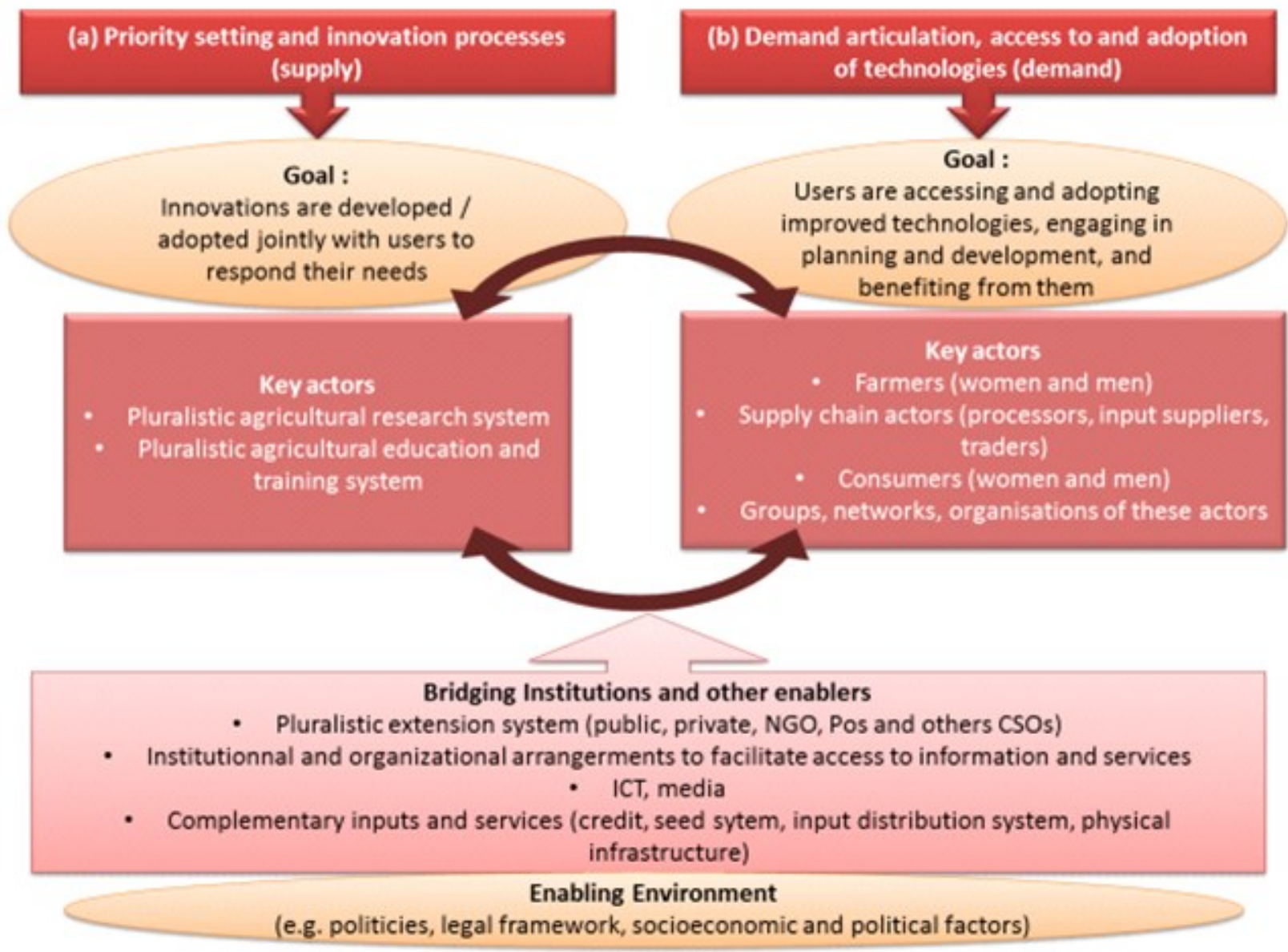

Figure 5. Conceptual framework in analyzing the demand and supply side of technological innovation while analyzing the role of institutions as catalysts and using a gender lens (Source: Ragasa et al., 2014).

\section{Small infrastructures and micro-irrigation}

Leduc (2011) under Western Upland Poverty Alleviation Project (WUPAP), Nepal, reported that the installation of small infrastructure and equipment in rural areas such as piped water equipment, water reservoirs, latrines, smokeless stoves, mills, pre-primary school, and roads have contributed to significantly reduce women's drudgery in the mountains, which are well appreciated by women. These types of intervention not only reduce the workload of women, they also improved their health and increase the opportunities for the girls, to access education. Upadhyay et al. (2005) demonstrated that the drip-irrigation systems in Nepal help in reducing women's workload and have a significant positive impact on family food and nutritional intake. Likewise, women's participation in vegetable farming under drip -irrigation tends to improve their rights to household resources, including food and cash. Since women are more involved in overall vegetable production, they have greater access to the cash generated from the sale of these vegetables. This improves their bargaining power and decision-making roles in the household. Moreover, women's participation in self-help groups, meetings and interactions among non-governmental organization staff and groups have helped them build their capabilities. In general, total time (mean hours) spent by women in vegetable production is significantly higher than those spent by their male counterparts. The analysis of time allocation data revealed that women's drudgery has been reduced by 50 percent with the drip irrigation as compared to conventional irrigation methods.

Small scale waste/roof water harvesting technologies (e.g. earthen pond, plastic sheet lining pond) are applicable, especially during the dry period; many disadvantaged households can partially supply water to vegetables, cash crops and help to reduce the workload of women for fetching irrigation water. ICIMOD, IFAD, FAO, Plan International Nepal and other many organizations have promoted and recommended this technology to reduce drudgery for women as well as crops diversification from low value cereal to high value vegetables for fetching higher income. Some research and project studies in Nepal showed that small scale irrigation system like treadle pump in Terai, drip irrigation systems in hills, sprinkler system connected to drinking water tap as a part of multiple water use system and rainwater harvesting plastic pond as well as ferrocement rainwater harvesting tank in hills reduce drudgery for women in agriculture sector (Dixit et al., 2013; Manandhar et al., 2009). Households can benefit from access to clean drinking water, irrigation facilities and other uses like water for livestock and cleaning from these small-scale irrigation technologies promotion and adoption. It also reduces the drudgery for women and small children who typically are forced to travel long distances and in hazardous conditions to collect water. The time saved would allow women to increase their income (productive needs) and improve their status in society (strategic need). 
Mechanization in agriculture and gender-friendly technologies Mechanization in agriculture reduces the drudgery of agriculture. However, the agricultural mechanization is low in Nepal, which is reflected in the types of agricultural machinery, tools and equipment used by the farm households. In this regards the data from the National Sample Census of Agriculture (NSCA) 2011/12 are summarized in Figure 5. The incidence of farm households with access to power tillers ( 2 percent), deep tube wells ( 4.2 percent), shallow tube wells ( 9.6 percent), pumping sets (14.3 percent), thresher (21 percent), tractor (22 percent) and iron ploughs (28 percent) are indicative of very low mechanization in agriculture in Nepal as of 2011/12 (Figure 6). The question here is how to promote capital formation at farm level that would have positive impact on reducing drudgery on labor and increases productivity.

A research conducted by LI-BIRD (2016) in Kaski and Dhading districts of Nepal showed that adoption of the jab planters and corn sheller help to reduce drudgery among rural women. About 80 percent of jab planter users liked the jab planter while all women liked the corn sheller for reducing drudgery. However, low access to input market of both these technologies, and the high price of jab planters might be a barrier to wider adoption and their up-scaling.

Out-migration of men and labor shortage has had a distinct influence on the mechanization of agriculture in Nepal, which has accelerated in the last two decades (Joshi et al., 2012). This is also partly due to the lack of attention in reducing drudgery in agricultural and rural operations for women, poor farmers and workers. Several power-operated agricultural machines are now in use in Nepal, including the following that reduce drudgery for women and poor farmers: water pumps, tractors both 4 wheel and 2 wheel, harrows, rotavators, seed drills; threshers; combine harvesters (for rice and wheat); agricultural processing machines; rice, oil and pulse mills; and laser and land-levelers. Biggs et al. (2011) reported that the mechanization technology and machines available across the long open border with India influenced mechanization patterns in the Nepal Terai. Minimum tillage by power tiller drills has been popular among small and medium farmers performing three operation of soil tilling, seed sowing and planking. It saves on cost, overcomes the problem of poor plant-stand and reduces women's workload for seed sowing that can result from poor tilth and manual broadcasting.
Minimum tillage by participatory technology development has produced an extra $600 \mathrm{~kg}$ per hectare mean grain-yield of wheat with typical yield based on farmers' practice (Manandhar et al., 2009).

Both wheat and rice threshers are becoming popular in most parts of the Terai because farmers see a clear advantage in terms of saving time, resources and labor. In addition, threshers reduce drudgery for women from manual threshing activities. The use of machines to thresh wheat is much higher than for rice, although rice threshers are beginning to spread in Nepal's eastern Terai (Joshi et al., 2012). Pedal millet thresher developed by AED/NARC and tested by LI-BIRD found that it has reduced women farmers' workload in threshing and pearling millet about 65-85 percent. Among the users, a total of 83 percent respondents (94.7 percent women) found pedal threshers to be important alternative for manual threshing. Farmers found pedal thresher effective for easy grain separation, cleaning, and removing husk while they reported that the pedal thresher requires less time and effort to operate, most importantly it avoids injuries on feet, and reduces backache compared to the manual threshing. However, identification of model with lighter weight, portability, and affordable price could help farmers reduce the labor and drudgery to address labor scarcity that are related with out-migration. Women farmers have demanded an electric thresher where they have access to electricity, they felt the leg pain while operating the pedal of the thresher (LI-BIRD, 2015).

Some agricultural machinery developed by NARC's AED like hand maize sheller, coffee pulper, thresher-cum-peeler for millet, and low-cost solar dryers are commercialized and adopted by farmers in various part of Nepal. The hand maize sheller reduces drudgery for women farmers. The coffee pulper has been adopted on a commercial scale at the community level, and has increased capacity and efficiency by 50 percent compared to manual operations related to these commodities (AED/NARC, 2014; Joshi et al., 2012; Manandhar et al., 2009). AED/NARC (2008) reported that adoption of small dryer for early rice (Mini $\mathrm{SRR}$ ) means not only the conservation of the early rice varieties products or seed during rainy season but also enabling the farmers to wait for better prices. The dryer for early rice would also help in reducing women drudgery as they are mainly involved in crop drying (Table 1).

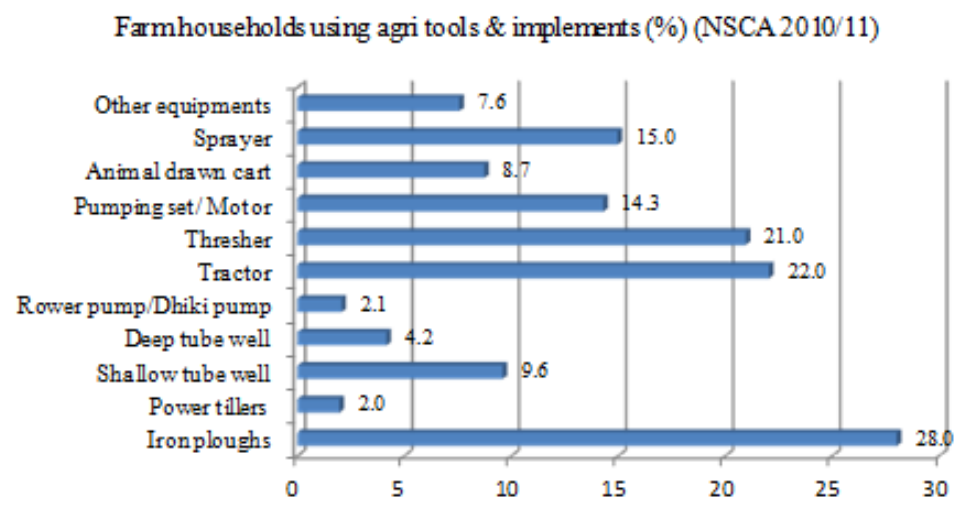

Figure 6. Farm households using agriculture tools and implements in Nepal (Source: CBS/NSCA 2012). 
Table 1. Some agricultural technology and machinery developed by AED/NARC that can reduce women's' drudgery in agriculture sector.

\begin{tabular}{ll}
\hline S.N. & Agricultural technology and machinery \\
\hline 1 & Zero minimum tillage technology \\
3 & Rice weeder \\
4 & Pedal paddy thresher for wheat thresher \\
5 & Manual corn sheller \\
6 & Water management technology for early rice and wheat \\
7 & Low cost solar dryer \\
8 & Improved cardamom dryer \\
9 & Improved plastic house for off-season vegetable cultivation \\
10 & Jab seeder/planter \\
11 & Coffee pulper \\
12 & Millet thresher cum pearler \\
13 & Mini SRR-Dryer \\
14 & Improved rotary quem \\
15 & Vegetable seed cleaner \\
16 & Pedal operated rice cum wheat thresher \\
17 & Ginger washing machine \\
18 & Dry land weeder \\
19 & Aerator \\
20 & Potato grader \\
\hline
\end{tabular}

Source: AED/NARC (2016)

A consultation meeting with Ishwori Prasad Upadhyay (Post Harvest Engineer) and Ganga Ram Bhandari (S1 Scientist), Agricultural Engineering Division/NARC, reported that small tractor ( 2 wheel) and hand machines are found more women friendly. Power tiller, drum seeder (for direct seeded rice), mini-tiller, rice weeder, corn sheller, dry land weeder, pedal thresher (for rice and wheat), dryer (solar/cabinet), pedal/ electric millet thresher, coffee pulper, potato grading machine, rainwater harvesting plastic pond, plastic tunnel for off-season vegetable production are women friendly technologies; these can help in reducing drudgery for women in agriculture sector. However, these technologies are not scaled up and have low adoption rate due to the poor information and dissemination strategy at local, regional and national level. The seventies emphasized that verification and testing of the technologies at farm level from gender perspective and awareness, and the capacity development training and programs during transitional phase should be needed for promotion of these technologies to a wider scale. Although government has provided up to 35 percent subsidy in machinery (25 percent in Terai, 30 percent in Mid-hills and 35 percent in High-hill Mountains), the small-scale farmers and women could not afford these technologies due to high costs, monopoly trade and lack of commercial agricultural machinery industries in Nepal. In this scenario, the private sectors' involvement for technology trading in collaboration of NARC and government and non-government sectors are visualized (I.P. Upadhyay and G.R. Bhandari, Personal Communication at AED/NARC office, Khumaltar, $3^{\text {rd }}$ October, 2016). Manandhar et al. (2009) also reported that the tubular corn sheller in maize growing areas, mini SSR dryer rice in early rice growing area during rainy season and low-cost solar dryer in drying agro commodities (apple, apricot fruits and vegetables) in the remote mid hills have high potential to reduce women's drudgery in agriculture sector effectively. Sapkota et al. (2007) reported that there is lack of technology that really support or reduce the drudgery and time used by women for tedious work as drying of seed for storage, shelling maize and weeding.

A consultation meeting with Agriculture Food Security Project, FAO, Dr. Bishnu Dhital, Agriculture Specialist, reported that power tiller, threshers (paddle and electric), corn sheller (hand and electric) are major technology promoted by FAO in western development regions of Nepal that help to reduce women's drudgery (Dr. B. Dhital, Personal Communication, $1^{\text {st }}$ October, 2016).

Some of the identified and tested women's drudgery reduction technologies in India are:

- $\quad$ Row manual rice trans planters: Singh (2009) from Bhopal India reported that two-row and four-row manual rice trans-planters could reduce drudgery by 36 percent and 70 percent, respectively in term of physical cost/ha as compared to traditional practices;

- Improved lighter tools, cattle troughs, rice mills, home garden;

- $\quad$ Single wheel hoe for weeding;

- A number of small tools and equipment have been designed by ICAR institutes, Universities and other agencies/ industries in India. Some of them that can be easily used by women and reduce drudgery are: Dibbler (suitable for drilling wheat, field pea, and maize in small plot); Dibbling Stick (sowing for seed); Rotary Dibbler; Paddy drum seeder; blade hand hoe, Three tined hand hoe (grubber), Single wheel hoe (for weeding of vegetable crops); Double wheel hoe (weeding and inter-culture for upland row crops); Cono -weeder (weeding for paddy); Groundnut decorticator; 
Tubular maize sheller; Fertilizer broadcaster for women; Hanging type grain cleaner; Transplanting trowels; Khurpi (for weeding); Hand fork; Hand sprayer; Sickles and Dao (cutting tools); Plucker; Pedal operated thresher; and Self-propelled riding type reaper.

Sustainable agriculture, resource conserving technologies and agro forestry

Nepal is one of the few countries (after India in 2014) to have the Agro-Forestry Policy 2019. Such policy have big importance to reduce the drudgery of work on woman in agriculture, livestock and forest related activities especially in the rural areas. This Agro-Forestry Policy 2019 (2076 BS) has the its objectives as follows: i) To increase productivity of the land and its multiple uses and thereby increase the output of agriculture, livestock and forest-based products; ii) To reduce pressure on forest and thus preserve the environment and bio-diversity, soil health (quality) and natural-ecological system restoration; iii) To make intensive uses of agro-forestry for the local people's food security, livelihoods, employment and income-generating opportunities; iv) To mobilize resources for agro-forestry for its commercial development for contribution in the economy; and v) To enhance capacity in the areas of agro-forestry for capacity building, study and research. There are some studies which indicate possible agency and methods to develop agro-forestry with reduced work burdens.

From field observation and farmer's experiences, it is found that there are many types of technology for reducing the world load for women; such technology include the on-farm green manuring, growing a green manure crop together with the main crop, incorporating the former at an early stage of the main crops, use of effective micro-organisms to shorten the composting period, vermi-compost, composting on planting pits, growing peas on the ridges after the rainy season potato harvest, cultivating potato under minimum tillage practice (bung system- as practiced in some eastern hills of Nepal), production of some high value perennial crops like akabare chilies, and kitchen gardening. Conservation agriculture (CA) and resource conserving technology (RCT) save time, inputs (fertilizers, fuel and labor) and natural resources (soil and water). Research findings showed that the RCT like minimum tillage by power till drill (PTD), direct seeded rice (DSR), zero tillage by zero till drill (ZTD) and system of rice intensification (SRI) help in reducing drudgery for women (Manandhar et al., 2009). Herbicides help to reduce drudgery for women in agriculture sector through saving weeding time that are mainly done by women. In cases where CA system are based on manual weeding, the labor burden of women and men can actually increase to an unsustainable level (Nyanga et al., 2012; Giller et al., 2009). Labor drudgery in manual weeding will be reduced, especially for women from application of herbicides (Nyanga et al., 2012).

Adoption of agro-forestry at homestead is found effective and relevant for reducing drudgery in rural areas of Nepal. A consultation meeting with Mrs. Rashmi Padit, Agriculture Officer, OXFAM reported that agro forestry promotion at homestead helps to reduce women's workload and save time to collect fodders and firewood from forest (Personal Communication, $4^{\text {th }}$ October, 2016). Tamang et al. (2014) in their study focus that less-labor intensive agro-forestry approach can be vital for drudgery reduction of women and thereby address the prevailing injustice in the agriculture sector. Karki et al. (2015) in their research study compared the hill leasehold forestry and forage development project (HLFFDP) intervention on curtailing gender dimension found that the participation of women in leasehold forestry in small group helps to reduce their drudgery in the livestock farming and agricultural production as compared to the non-project intervention. This is due to the high involvement of the project women in group activities such as training, group meeting, plantation of fodder, forage cultivation, nursery management and land terracing, track construction and other activities as well as easily availability of the fodder, forage for livestock feeding and the firewood from the leasehold forestry system. Consultation with Agriculture and Forestry University (AFU)' horticulture manager revealed that plastic mulching in vegetable farming help to reduce work load for weeding and increase productivity (R. B. Neupane, Horticulture Manager, AFU, Rampur, $7^{\text {th }}$ October, 2016).

Access to information, communication and technology (ICTs) and finance

Some research conducted in Asian countries indicated that adoption of mobile phone and ICTs by women help in drudgery reduction for women in agriculture sector, and improve their access to inputs, services and market linkage, and the women empowerment. For example, Sylvester (2016) reported that gender does have some effect on how the phone is used. Women use it more for coordination whereas men, on the other hand, seem to use it more for livelihood activities and for making and maintaining social connection. However, men in general have greater decision-making power in phone purchase even for their spouse. The relative difference between men's and women's access to and usage of ICT like, mobile phones is diminishing. Many studies have shown that in rural areas men are more likely to won and have access to phones than women. Other factor associated with more access to phones are greater levels of illiteracy, cultural barriers, and less available cash and access to credit (Ragasa et al., 2014).

A number of studies highlight the lack of access to information about technologies or the lack of required complementary knowledge and skills to use technologies as hindrances to a faster adoption of new technologies and improved management practices (Tiwari, 2010; World Bank and IFPRI, 2010). Mobile phones also offer great opportunity for women and men, especially in remote area, to be connected with information relevant for their livelihood and reduced drudgery for poor farmer and women. The Grameen Phone Project-2005 that specifically targeted women in Bangladesh is a good example of the successful use of mobile phones in agriculture extension. Women received learning the modules related to goat and sheep enterprises through their mobile phones while they tended to overcame the 
barrier imposed by time constraint and save their time. Other ICT like FM, community radio, internet-based posting of questions and answer (only for commercial and well-educated farming women) including mobile phone and computers have played a key role in empowering women and strengthening women knowledge base. In the developing countries, ICTs have been increasingly used to disseminate information about technology, market, management practices, and to reduce women's drudgery and increase their decision-making power on use and control over the resources. The women in Nepalgunj mentioned that mobile phone helped to reduce transaction costs and increased profit. They no longer have to pay for transport costs to sell their produce to the local markets as their clients came directly to their homes. They were also able to establish loyalty with existing clients and increase clientele base (UN Women, 2016). In this regard, women can also make best use of mobile phone and other ICTs (FAO, 2016).

Access to credit from the financial institutions (bank, cooperatives, micro-finance institutions) and access to the extension services among women can help for reducing the women's drudgery in agriculture sector by empowering them on the use and control over resources, agribusiness promotion and marketing. For example, Khadka (2014) reported that access to credit among women from Small Farmer Cooperative Limited in Sarlahi empowers them in the level of confidence, ability to communicate, make a decision and acknowledgement by family that ultimately helps in drudgery reduction of women. Further, complement this with the access to collection centers, storage facilities, technology for processing, certification for exporting, other technology to reduce drudgery, specialization, crop and livestock insurance and use of ICTs.

Women, small-holder and excluded group's access to credit remains very limited. Although microfinance has played a vital role in strengthening women's access to credit over the years, the Nepali microfinance system has reached only 37 percent of the population, and even that in the most accessible areas. Microfinance has not helped women's access to credit from banks and financial institutions. Lack of land and other productive resources prevent women from meeting the collateral requirements for accessing larger amounts of credit. About 72 percent of small holders still rely on the informal sources of credit, which often charge the exorbitant amounts of interest. Women and excluded groups often have low mobility and, therefore, low access to information about financial services (UN Women, 2016). A case study in Baglung and Palpa districts from Community Base Maize Seed Program (CBMSP) by Sapkota, Shrestha and Joshi (2007) highlighted that women's limited control over agricultural resources is a barrier to their access to the production credit, equipment and resources. Increase the capacity of women and excluded groups to gain access to the market information (prices) and increase market intelligence (viz capacity of knowing and understanding opportunities for exchange and investments) through training, awareness, development of pro-poor ICT products helps to reduce drudgery (UN Women, 2016).
Socio-demographic and institutions factors

Many studies show that socio-demographic characteristics (such as location, age, marital status, family type, education, occupation and male out-migration) and institutional aspects (like capacity development, awareness, memberships, access to financial service) may have positive or negative effect on reducing women's drudgery in Nepal. Education of women can help reducing women's drudgery in agriculture sector through better information, communication and awareness on farm technologies whereas better occupation may also help in drudgery reduction for women in agriculture sector. However, educated and professional occupation women can have less drudgery in agriculture but increase drudgery in household chores due to socio-cultural structure (Y. Ghale, SDC, Personal Communication, $1^{\text {st }}$ October, 2016).

Ghimire et al. (2015) in their study in central Nepal revealed that access to education, extension services and seeds play significant roles in adoption decisions of new improved rice varieties. Similarly, Paris and Thi Ngoc Chi (2005) in Southern Vietnam reported that progressive farmers - who have more frequently contact with extension workers, who have better-educated wives and who use low seed rates -- are more likely to adopt row seeders for rice transplantation that reduced drudgery for women.

Many studies show that out-migration of men household members and remittance received both positive and negative effect on drudgery reduction for women. Tamang et al. (2014) reported that feminization of agriculture has impacts on both the social and economic spheres. The study specifically focuses on the change in women's workload, the expansion of their roles, their ownership and access to productive resources, and the part they play in household decision making. The study conducted by Maharjan et al. (2012) in rural areas of Nepal suggest that women have broadened and deepened their involvement in rural society as a result of male out-migration, which could lead to either the empowerment or disempowerment of women. Several project reports show that the self-help groups (SHG), group membership in saving credit groups and cooperatives, women's land ownership and land right can reduce women's drudgery in agriculture sector in South Asia (Leduc 2011: project assessments findings from Nepal and India). The women, Dalit and members of other excluded groups' participation in lucrative markets has been limited due to the lack of capital, restrictions on mobility, inability to access strong commercial networks and knowledge of demand and supply, and other sociocultural determinants. Under development in rural infrastructure is also a cause for concern - although good practices are proliferating (UN Women, 2016).

Agribusiness and commercialization in agriculture

Agribusiness development through the value chain approach and through the products to market linkage activities can help women's drudgery reduction, and empower them on decisionmaking. In addition, it helps women to use and to have control over the financial and other resources in the product-process function and in value-chain upgrading with improved governance. Many project studies and gender-inclusive value chain 


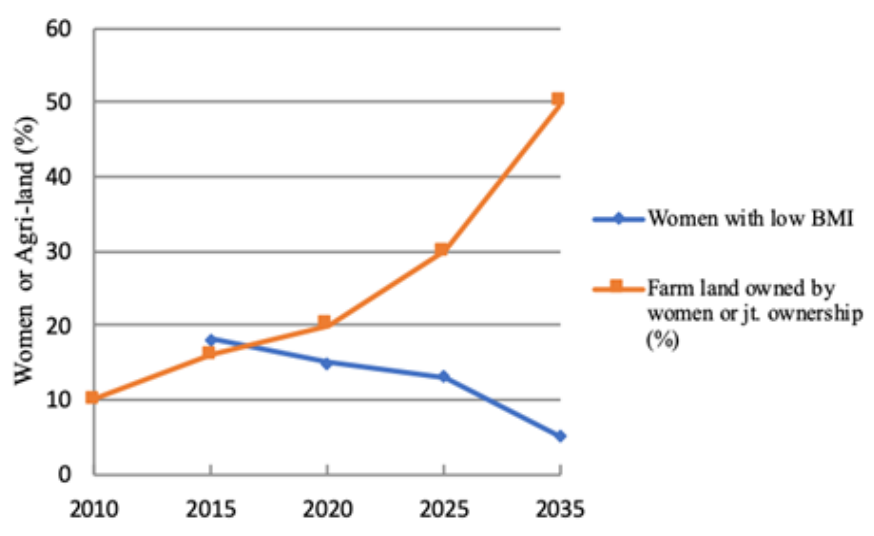

Figure 7. Place of women in the ADS in Nepal.

analysis reports have highlighted the women empowerment and their drudgery reduction through the technology intervention in inputs, production, processing, and through the collective marketing approach. Here some examples include the findings from bi-lateral and multi-lateral projects value chain assessment in Nepal by Landon-Lane et al. (2016). Further, Gurung et al. (2016) in Bangladesh reported that the transformation from rice farming to commercial aquaculture not only decreased the workload of women but also, on the contrary, weakened their access to and control over agricultural products.

Engendering value chain development in agriculture and forest sectors can empower women and workload sharing between family members for value chain functions and upgrading practices that help reduced the women's drudgery (for examples, Bhattarai et al., 2009; ICIMOD, 2009; Hoermann et al., 2010). Women involvement in value chain development can reduce household chores. Adhikari (2006) reported that the commercialization and feminization of vegetable farming have empowered women on decision making, income sharing as well as reduced their drudgery in household chores. Insufficient business skills and lack of access to marketing also hinder the growth of women's enterprises. Lack of skills in entrepreneurship, product development, insufficient theoretical and practical training are major obstacles identified by some women entrepreneurs (Amatya Shrestha et al., 2010).

\section{Engendering in research and extensions}

The issues of gender in agricultural technology research are about how to involve the women-farmer clients in setting the research agenda around three areas, namely, i) agricultural production and post-harvest processing, ii) information technology, and iii) energy. There need to be in place a National Agricultural Research System (NARS), which should have a substantial presence of the women-farmers in its governing body to define the research agenda and strategy. Such things are limited in Nepal's NARS. Similarly, the Nepal need to have National Extension Strategy (NES) to include at least to issues, namely, the women have larger presence in the cadre of the extension staff, and the extension staff would need to function not merely as carrier of the technology-messages bust as facilitators with women-farm clients for collaborative approaches to manage the farms profit-

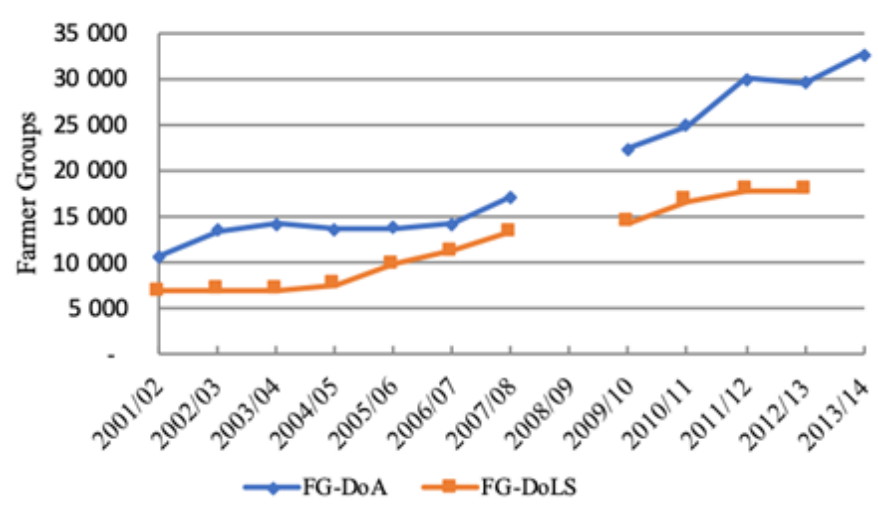

Figure 8. Agriculture extension coverage to the farmer groups in DoA and DoLS in Nepal.

ably. The NARC's Strategic Vision for Agricultural Research (2011-2030) has mentioned that the technological development and dissemination need to be sensitive to the conditions of rural women, whose contribution is often greater than that of men in the production, storage, processing and marketing of crop, livestock and fishery products, and in the collection, use, and management of natural resources. Under the new strategy, agricultural research has prioritized to ensure that the gender concerns are properly accounted, but it does not specify how to mainstream the gender roles in agriculture and reduce women's drudgery through the gender-neutral and sensitive technology development and its disseminations (NARC, 2010).

The gender sensitive research projects should contribute to reducing gender inequality by women's participation in technology and inputs development and dissemination through the research and extension bridging. One of the tools that agriculture research project can consider is the Participatory Action Selection (PAS) and Community-Based Participatory Research (CBPR). For example, Deuti maize variety released by the National Seed Board (developed from NARC) is not womenfriendly and the women from mid-hill have not preferred this variety due to its deep-root system, which needs more energy for uprooting (Dr. K. K. Mishra, Chief, M \& E Division, NARC, Personal Communication, $2^{\text {nd }}$ October, 2016). Thus, in participatory variety trial and selection process women involvement would be needed for testing and verification of seeds and other inputs.

Maize qualities preferred by men and women are quite similar. But the women farmers need a variety with longer storage durability as they generally use their leisure period to shell the maize. It is essential to add the longer storability character of maize into the research program to emphasize in the needs of the women and their for the welfare of society and gender encouragement by growing gender-biased variety of maize; thus the scientist need to include the preferred attribute quality of maize to reduce the women's drudgery (Sapkota et al., 2007). Women exclusively carry out certain maize production activities /operations. This the gender gap in agriculture research and extension is addressed. Research should focus on those women specific activities/operations in order to reduce their workload and increase their working efficiency. Therefore, women 
involvement should be increased in the research programme so that the women feel more enthusiastic to participate, can gain more knowledge and skill, and feel free to cooperate ; such approaches will be accelerating factor to generate the need-based technology from the gender perspectives (Sapkota et al., 2007). Various findings show that the conservation agriculture, resource conserving technology and sustainable agriculture practices related research, extension and dissemination can help to reduce women's drudgery (SSMP, 2010b; Manandhar et al., 2009). However, very few research study and extension activities have been done at the research stations (NARC) and other government sectors in Nepal. In addition, more research and extension is necessary to engendering in agribusiness development through value chain approach, to increase competitiveness from the point of view of the women's workload reduction, and sharing of such outputs. NARC needs to have focus on participatory technologies development (PTD) and scaling-up strategy by adopting emerging model of technology develop and transfers e.g. the AKIS and NSI perspectives on GESI inclusion in the core activities.

\section{Agriculture Development Strategy (ADS)}

The ADS of Nepal is a 20-year strategy of agricultural development (2015-2035). The importance of integrating GESI provision has been recognized throughout the ADS process. GESI provisions are more explicitly integrated in the 'Governance' pillar of the ADS. But the GESI inclusion is equally importance in other three pillars pertaining the productivity, profitable commercialization and competitiveness. The ADS envisages a high progress about welfare of the women in terms of reduction in the incidences of low body mass index (BMI) from 18 percent to 5 percent during 2015-35. Part of this improvement is expected to occur through improvements in the landownership by women from 16 percent to 50 percent during 2015-2035 as indicated in Figure 7. However, the ADS is silent on quantifying either the proportion of the women in the agricultural research or technology cadre. Similarly, the extension system is based on farmers groups, which are available for the farmer groups (FGs) under the Department of Agriculture (DoA) or the FGs under the Department of Livestock Services (DoLS) as shown in Figure 8 . However disaggregated planning by gender-specific farmers groups are lacking. Thus, at the policy, planning and program levels, there is need for gender-disaggregated data for technical modernization of agriculture.

In the ADS, it need to address the agricultural labor shortage due to migration of youths particularly men to third countries. Further, the gender equality and social inclusion (GESI) focal points at NARC and GESI-staff at the central level and at district level should promote GESI-responsiveness in program design and implementation mentioned in ADS. The findings show that ADS need to mainstream women in its all four pillars (governance, productivity, profitable commercialization, and competitiveness) to reduce their drudgery in agriculture sector; this can be done by embedding the women-friendly programs and innovations throughout the ADS process in the develop- ment programs at the district, municipal and community levels.

\section{Conclusion}

Feminization of agriculture in Nepal is evident from the out-migration of male for better job opportunities to abroad or city areas. It has increased burden for women to sustain the agriculture sector inputs the household chores. Many scholars have shown that women's work load has been increasing as compared to men counterpart in agriculture sector. The findings from desk review of existing research studies reveals that the multidimensional factors to contribute for women's drudgery reduction in the agriculture sub-sectors in Nepal. The desk reviews show that various characteristics and variables act together to influence the drudgery reduction for women in agriculture such as: i) socio- demographic (location, age, marital status, family type, education, occupation and outmigration); ii) economic (access to road, energy, infrastructure, technologies, land ownership, other property right, access to ICT, agribusiness development through value chain approach); iii) institutional (capacity development, awareness, memberships, access to financial and service); and iv) other framework variables (like access to extension service, work load and income distribution and sharing).

Considering above aspects, the workload of women (time and energy) spent on on-farm activities can be reduced in two ways:

- Making existing tasks easier or increasing the productivity of existing labor, and

- Changing farm practices and/or introducing new technologies and practices.

It is further suggested that the Nepal Agricultural Research Council (NARC) need to have women farmers' represented in its governing body to set agenda for women-friendly agricultural technology. Similarly, Nepal needs to have a national extension strategy (NES). The agricultural technology (research and extension) should be client based, collaborative, pluralistic, market-oriented as well public-service oriented. The agricultural technology and other support institutions are overdue for redesigning also from the point of federal governance, which has three-tiers, namely, the Central, Provincial and (rural) Municipal levels. More specifically, the programs of NARC DoA, DOLS and cooperatives need to build up for the women coverage through: i) effective extension service based on twoway communication of the technology and farmers' problems and approaches; ii) functional and business literacy for farmerbased knowledge, agribusiness, farming, iii) support for financial, technical, agro-processing, irrigation and water management, labor management, and tools and technology; iv) priority in exposure training for women farmers; v) access of women to land and their entry in the ward levels cooperatives and groups; vi) marketing support to women for their products through municipal level worn farmers associations, and empha- 
sis on whole farm management and household technology and well-being. Such measures will also contribute to implementing different indictors of the SDG 2030 agenda (SDG 1-8 and 10: no poverty, zero hunger, good health and wellbeing, quality education, gender equality, clean water and sanitation, affordable and clean energy, decent work and economic growth, and reducing inequality) as well.

\section{ACKNOWLEDGEMENTS}

The research was supported financially and technically by the UN Women, Nepal. We are grateful to Dr. Y. B. Thapa for his encouragement and valuable suggestions and updated data information. We are also deeply indebted to concerned stakeholders in our study area, who are too numerous to mention individually, but without whose cooperation this study would not have been possible. Errors, if any, are entirely our own.

Conflict of interest: The authors declare there are no conflicts of interest

Open Access: This is an open access article distributed under the terms of the Creative Commons Attribution 4.0 License, which permits unrestricted use, distribution, and reproduction in any medium, provided the original author(s) if the sources are credited.

\section{REFERENCES}

Adhikari, R. (2006). Economic dimension of empowerment: Effects of commercialization and feminization of vegetable farming on social status of women in an urban fringe of western Nepal. Himalayan Journal of Sociology \& Anthropology, III:86-105.

AED/NARC (2016). Agricultural Engineering Division' Leaflet NARC Series No.: 00353-166/2016/017. Khumaltar Lalitpur, Nepal: Nepal Agricultural Research Counsil (NARC).

AED/NARC (2014). Annual Report 2013/14. Agricultural Engineering Division (AED)/ Nepal Agricultural Research Council (NARC).

AED/NARC (2008). Mini SRR: Small dryer for early rice. National Insitute/Asia and Pacific Center for Agricultural, Engineering and Machinary, Nepal 2008: AED/NARC

Amatya Shrestha, S.M., Nepali, M.B., Gautam, S. and Sharma, B. (2010). Gender involvment in rice production system in the western terai region of Nepal: $A$ case study of Bankati and Madanpokhara site. In B. Kafle, A. P. Poudel and M. N. Poudel (Ed.), Proceedings of the 9th National Outreach Research Workshop, 7-8 June, 2010 (p. 183). Outreach Research Division, NARC, pp. 158165.

Bhattarai, B., Leduc, B., Choudhary, D. and Pandit, B. H. (2009). Engendering the value chain: The case of community based bay leaf enterprise in Nepal. Kathmandu: ICIMOD.

Biggs, S. and Justice, S. (2011). Transport and diverse pattern of agricultural mechanization: Reopening the rural development and energy policy debates.

Biggs, S., Justice, S. and Lewis, D. (2011). Patterns of rural mechanization, energy and employment is South Asia: Reopening the debate. Economic and Political Weekly, XLVI (9): 78-82.

CBS/NASC (2012). NASC Data set; National Agriculture and Sample Census, 2011. Thapathai, Kathmandu, Nepal: Central Bureau of Statistics.

CBS/NPHC (2011). NPHC Data set; National Population and Housing Census dataset, 2011. Thapathali, Kathmandu, Nepal: Central Bureau of Statistics.

CBS (2016). Annual Household Survey 2014/15. Major Findings. Kathmandu, Nepal: Government of Nepal, National Planning Commission Secretariat, Central Bureau of Statistics.
CBS (2012). National Population and Housing Census 2011. Government of Nepal, Central Bureau of Statistics.

CBS (2019). Report on the Nepal Labour Force Survey (NLFS III) 2017/18. Central Bureau of Statistics, Nepal.

CBS (2008). Report on the Nepal Labour Force Survey (NLFS II) 2007/08. Central Bureau of Statistics, Nepal.

CBS (1998). Report on the Nepal Labour Force Survey (NLFS I) 1998/99. Central Bureau of Statistics, Nepal.

Dixit, A., Shukla, A. K., Shrestha, R., K.C, J. and Bishwakarma, D. R. (2013). Proceedings of national seminar on Small scale irrigation: Experiences, challenges, opportunities and pathway. Kathmandu: Institute for Social and Environmental Transition-Nepal (ISET-Nepal).

FAO. (2016). Use of Mobile Phones by The Rural Poor: Gender Perspectives from Selected Asian Countries. FAO, IDRC and LIRNEasia.

FAO (2010). Intergration of gender in agriculture: An analysis of situation. UN Complex, Pulchowk, Nepal: Food and Agriculture Organization of the United Nations.

FAO (2011a). The role of women in agriculture. Prepared by SOFA team and Cheryl Doss. Agricultural Development Economics Division. The Food and Agriculture Organization of the United Nations.

FAO (2011b). The State of Food and Agriculture 2010-11: Women in Agriculture; Closing the Gender Gap for Development. Food and Agriculture Organization (FOA), Rome.

FAO (2005). Rural women and food security in Asia and the Pacific: Prospects and paradoxes. FAO Regiona IOffice for Asia and the Pacific, RAP Publication 2005/30, ftp://ftp.fao.org/docrep/fao/008/af348e/af348e00.pdf.

GoN/ADS (2014). Agriculture Development Strategy (ADS). Ministry of Agriculture Development, Government of Nepal, Kathmandu, Nepal.

Gartaula, H. N., Niehof, A. and Visser, L. (2010). Feminisation of agriculture as an effect of male out migration: Unexpected outcomes from Jhapa District, Eastern Nepal. The International Journal of Interdisciplinary. Social Sciences, 5 (2): 565-577.

Ghale, Y. (2008). Scoping study on women's Leadership in the agriculture sector in Nepal. Women Organizing for Change in Agriculture and NRM (WOCAN), Kathmandu, Nepal.

Ghebremichael, B. (2013). The Role of Cooperatives in Empowering Women. Journal of Business Mangement and Social Research, 2 (5): 51-54.

Ghimere, H. K. (2008). Harnessing of mini scale hydropower for rural electrification in Nepal. Hydro Nepal. Journal of Water, Energy and Environment, 1: 2628.

Ghimire, R., Wen-Chi, H. and Shrestha, R. B. (2015). Factors affecting adoption of improved rice varieties among rural farm households in central Nepal. Rice Science, 22 (1): 35-43.

Giller, K. E., Witter, E., Corbeels, M. and Tittone, P. (2009). Conservation agriculture and smallholder farming in Africa: The heretics' view. Field Crops Research, 114 (1): 23-34.

Gurung, A., Ian, B. and Sang-Eun, O. (2011). Mico-hydropower: A promising decentralized renewable technology and its impact on rural livelihoods. Scientific Research and Essays, 6 (6): 1240-1248.

Gurung, K., Bhandari, H. and Paris, T. (2016). Transformation from rice farming to commercial aquaculture in Bangladesh: Implications for gender, food security, and livelihood. Gender, Technology and Development, 20 (1): 49-90.

Hoermann, B., Choudhary, D., Choudhury, D. and Kollmair, M. (2010). Integrated value chain development as a tool for poverty alleviation in rural mountain areas: An analytical and strategic framework. Kathmandu: ICIMOD.

ICIMOD (2009). Engendering value chain development. The International Centre for Integrated Mountain Development (ICIMOD), Kathmandu, Nepal.

Joshi, K.D., Conroy, C. and Witcombe, J.R. (2012). Agriculture, seed, and innovation in Nepal: Industry and policy issues for future. International Food Policy Research Institute (IFPRI).

Karki, L.B., Siegfried, B., Karki, U. and Joshi, N. B. (2015). Women's empowerment and farm productivity: A case of project intervention. Nepalese Journal of Agricultural Economics, (2-3): 163-177.

Kattel, R. R., and Uphadhyay, N. (2018). Out-migration and remittances in Nepal: Is this boon or bane?. Journal of Agriculture and Forestry University (JAFU), (2): 6372.

Khadka, N. (2014). Empowerment of women through microfinance in Jabdi Village Development Committee, Nepal. Mater Thesis 2014. Norwegian University of Life Science, Faculty of Social Science, Department of International Environment and Development Studies. 
Kelker, G. (2009). The feminisation of agriculture in Asia: Implication for women's agency and productivity. New Delhi: The United Nations Development Fund for Women (UNIFEM).

Kollmair, M. and Hoermann, B. (2011). Labour migration in the Himalayas: Opportunities and Challenges. Sustinable Mountain Development. No. 59 Summer 2011. ICIMOD, Kathmandu, Nepal.

Khadka, M. (2012).World Environment Day: Women at the forefront. The Kathmandu Post (5 June 2012), http:// ekantipur.com/2012/06/05/opinion/ world-environment-day--women-at-the-forefront/355087.html.

Khadka, N. (2014). Empowerment of women through microfinance in Jabdi Village Development Committee, Nepal. Mater Thesis 2014 . Norwegian University of Life Science, Faculty of Social Science, Department of International Environment and Development Studies.

Landon-Lane, C., Kattel, R. R. and Thapa, B. (2016). Study on Achievements, Lessons Learned and Way Forward on Agriculture Development through a Value Chain Approach (Unpublished). Value Chain Assessment, Asian Development Bank, Nepal Resident Mission, Kathmandu, Nepal.

Leduc, B. (2011). Mainstreaming gender in mountain development: From policy to practice. Lessons learned from a gender assessment of four projects implemented in the Hindu Kush-Himalayas. ICIMOD, Kathmandu, Nepal.

LI-BIRD (2016). Annual Report 2014-15. Local Initiatives for Biodiversity, Research and Development (LI-BIRD), Pokhara, Nepal.

LI-BIRD (2015). Annual Report 2013-14. Local Initiatives for Biodiversity, Research and Development (LI-BIRD), Pokhara, Nepal.

Maharjan, A. (2010). Labour outmigration and its impact on farm families in the Mid Hills of Nepal (Vol. 113). In W. Doppler and S. Bauer (Eds.), Margraf Publisher, Germany.

Maharjan, A., Bauer, S. and Knerr, B. (2012). Do rural women who stay behind benefit from male out-migration? A case study in the Hills of Nepal. Gender, Technology and Development, 16 (1): 95-123.

Manandhar, G. B., Adhikary, S. K. and Sah, G. (2009). Sustainable agricultural practices and technologies in Nepal. NARI, Nepal Agriculture Research Council (NARC), Khumaltar, Lalitpur, Nepal.

MoAD (2018). Selected Indicators of Gender and Social Inclusion in Agricultural Programs: 'Abeneficiaries Statistics BookLet' (published Occasion of International Women's Day 8. March 2018. Kathmandu: Ministry of Agriculture Development. Food Security, Agribusiness Promotion and Environment Division, Gender Equity and Social Inclusion Section.

MoF (2019). Economic Survey 2018/19. Government of Nepal, Ministry of Finance, Singhdurbar, Kathmandu, Nepal.

MoF (2012). Economic Survey 2011/12. Government of Nepal, Ministry of Finance, Singhdurbar, Kathmandu, Nepal.

NARC (2010). NARC's Strategic Vision for Agricultural, Meeting Nepal's Food and Nutrition Security. Nepal Agricultural Research Council, June 2010.

Nyanga, P.H., Johnsen, F.H. and Kalinda, T.H. (2012). Gendered impacts of conservation agriculture and paradox of herbicide use among smallholder farmers. International Journal of Technology and Development Studies, 3 (1): 1-24.

Paris, T. R. and Thi Ngoc Chi, T. (2005). The impact of row seeder technology on women labour: A case study in the Mekong Delta, Vietnam. Gender, Technology and Development, 9 (2): 157-184.
Parker, H., Oates, N., Mason, N., Calow, R., Chadza, W. and Ludi, E. (2016). Gender, agriculture and water insecurity. Overseas Development Institute (ODI)

Poudel, K.P., Dahal, D. and Shah, R. (2012). Abandoned agricultural land in Mid Hills of Nepal. Community for Development Studies, Kathmandu, Nepal.

Ragasa, C., Sengupta, D., Osorio, M., OurabaHaddad, N. and Mathieson, K. (2014). Gender-specific approaches, rural insitutions and technological innovation. Rome: Food and Agriculture Organization of the United Nation (FAO).

Sapkota, S., Shrestha, B. and Joshi, K. R. (2007). Women's role in participatory research: A case study of CBMSPP in Baglung and Palpa districts. Proceed ings of the 8th National Outreach Research Workshop, 19-20 June 2007, (pp. 362-368). Outreach Research Division, NARC.

Sharma, B. (2010). Engendering energy and empowering women in the Himalayan Region: Some critical issues and options. Sustainable Mountain Development, ICIMOD, Kathmandu, Nepal.

Shiva, V. (1997). Most Farmers in India are Women. New Delhi: Food and Agriculture Organization. In: S. Tamang, K.P. Poudel, and K.K.Shrestha (2014). Feminization of agriculture and its implications for food security in rural Nepal. Journal of Forest and Livelihood, 12 (1): 20-32.

Singh, S.P. (2009). Physiological workload of women workers in the operation of manual rice tranplanters. Gender, Technology and Development, 13 (2): 271 284.

SSMP (2010b). Farmer Profile from the Mid-Hills of Nepal, A collection of individual stories from partners of the Sustainable Soil Management Programme Vol. 2, June 2010, Document No 161.Bakhundol Lalitpur. SSMP/ Helvetas Swiss Intercooperation Nepal.

Sylvester, G. (2016). Use of mobile phones by the rural poor: Gender perspective from selected Asian countries. Food and Agriculture Organization (FAO) and International Development Research Center (IDRC), Bangkok, Thailand.

Tamang, S., Poudel, K.P. and Shrestha, K.K. (2014). Feminization of agriculture and its implications for food security in rural Nepal. Journal of Forest and Livelihood, 12 (1): 20-32

Tiwari, N. (2010). Economic and technological constraints facing rural women International Journal of Rural Studies, 17:1-5.

Upadhyay, B., Samad, M. and Giordano, M. (2005). Livelihoods and gender roles in drip-irrigation technology: A case of Nepal. Working Paper 87. International Water Managment Institute (IWMI), Colombo, Sri Lanka.

UN Women (2016). Strengthening gender equality and social inclusive provision in Nepal's Agricultural Development Strategy. Submitted by UN Women to the ADS Team, MoAD, Nepal.

UNDP (2018.) Human Development Indices and Indicators 2018 Statistical Update.

World Economic Forum (2017). The global gender gap report 2017.

World Bank (2009). Gender in agriculture sourcebook. The World Bank, Food and Agriculture Organization and International Fund for Agricultural Development.

World Bank and IFPRI (2010). Gender and governance in rural services: Insight from India, Ghana, and Ethiopia. IFPRI and World Bank, Washington DC.

World Bank, FAO and IFAD (2008). Gender in Agriculture Sourcebook. World Bank, Washington, DC.

World Bank Group (2019). World Development Indicator 2019. World Bank Group, http://datatopics.worldbank.org/world-development-indicators/. 